Volume 11|Issue3

August 2020

\title{
Being Indigenous in an Unlikely Place: Self- Determination in the Yakut Autonomous Soviet Socialist Republic (1920-1991)
}

Evgeniia Sidorova

University of Calgary, Canada, evgeniia.sidorova@ucalgary.ca

Roberta Rice

University of Calgary, Canada, roberta.rice@ucalgary.ca

Recommended Citation

Sidorova, E., \& Rice, R. (2020). Being Indigenous in an Unlikely Place: Self-Determination in the Yakut Autonomous Soviet Socialist Republic (1920-1991) The International Indigenous Policy Journal, 11(3). https://doi.org/10.18584/iipj.2020.11. 3.8269 


\title{
Being Indigenous in an Unlikely Place: Self-Determination in the Yakut Autonomous Soviet Socialist Republic (1920-1991)
}

\begin{abstract}
How and why is Indigeneity expressed differently in different contexts? This article examines the articulation and expression of Indigenous Rights in one of the most challenging contexts—that of Siberia in the Soviet Union era. Based on primary, archival research carried out in the Republic of Sakha, Russia, the review finds that re-claiming and re-defining Indigeneity can serve as the first step in crafting an effective challenge to the domination and control exercised by states over Indigenous populations. The study of Indigeneity in unlikely places has important ramifications for Indigenous Peoples worldwide who are struggling against colonial-minded governments that have not only deprived Indigenous Peoples of their lands and resources, but also suppressed their right to selfidentification through imposed administrative definitions of Indigeneity.
\end{abstract}

Keywords

Indigeneity, self-identification, self-determination, Sakha, Russia, Soviet Union

Creative Commons License

(c) (1) (9)

This work is licensed under a Creative Commons Attribution-Noncommercial-No Derivative Works 4.0License. 


\section{Being Indigenous in an Unlikely Place: Self-Determination in the Yakut Autonomous Soviet Socialist Republic (1920-1991)}

Self-identification is a fundamental principle in the struggle for Indigenous rights worldwide. Yet, this principle is frequently denied by governments through their policies and practices. Indigenous Peoples are not ethnic minorities in need of institutional mechanisms to ensure their political inclusion, but instead are self-determining peoples or nations with unique rights and representational needs as recognized in international conventions, most notably the 1989 International Labour Organization's (ILO) Convention 169 (C169) - Indigenous and Tribal Peoples (1989), and the United Nations Declaration on the Rights of Indigenous Peoples (UNDRIP, 2007). Whereas ethnic minorities often seek better integration into state structures and institutions, Indigenous groups tend to seek greater autonomy from the state (Alfred, 2009; Papillon, 2012). Despite growing recognition that Indigenous political representation should be treated separately from that of ethnic minority representation, many governments continue to conflate the two (Bird, 2014; Kroeber, 2017; Krook \& O’Brien, 2010; Lublin \& Wright, 2013). As Canessa (2018) has pointed out, there are many cases of peoples recognized as Indigenous in Geneva (ILO headquarters) or New York (UN headquarters) but not in their own countries. Re-claiming and re-defining Indigeneity can serve as the first step in crafting an effective challenge by unrecognized Indigenous Peoples to the domination and control exercised by state authorities. With this objective in mind, our article addresses the central question: How and why is Indigeneity expressed differently in different contexts? It is not enough to simply state that things are different in different countries. We need to understand what drives these differences as a means of bringing about positive change.

This article examines the articulation and expression of Indigenous identity and rights in one of the most challenging, and perhaps least studied, cases — that of Siberia in the Soviet Union era (1920-1991). In the Union of Soviet Socialist Republics (USSR) and contemporary Russia, only Indigenous groups whose populations are less than 50,000 are recognized by the government as Indigenous Peoples (Consultant Plus, 1999; Sidorova, 2019). Larger Indigenous groups, such as the Yakut (Sakha) people who are the focus of this article, are frequently categorized as ethnic minorities or titular nations (Balzer \& Vinokurova, 1996; Laruelle, 2013). However, titular nation and ethnic minority are not legal terms in Russia. ${ }^{1}$ As Khazanov (1995) noted, in the Soviet Union, the status of being an ethnic minority was a matter of arbitrary decision-making by the State (p. 98). The situation of the Yakut (Sakha) people is especially complex owing to their lack of Indigenous recognition within Russia as well as the longstanding dispute over the Indigeneity criterion of "first occupancy" in this case (Okladnikov, 1955). The Soviet Union era policy of korenizatsiia (nativization) established autonomous republics for large Indigenous groups in exchange for their incorporation into the political system along class lines and their commitment to communist principles. Nevertheless, as our research reveals, Indigenous cultural expressions persist, even in the least likely scenarios. State-controlled definitions of Indigeneity are about control and the power to define "others." They reveal more about the character of the state than they do

\footnotetext{
${ }^{1}$ The terms titular nations and ethnic minorities are, however, commonly used in the academic literature. For example, according to Slezkine (1994), the Sakha are members of titular nationalities that reside in "their own" republics (p. 450).
} 
about the Indigenous Peoples living within its borders (Forte, 2013). They can also be inflected and reworked by social actors.

This study is based on a collaborative research project undertaken by an Indigenous-identified scholar, who was born and raised in Siberia (Sidorova), and a settler-ally scholar from Canada who specializes in global Indigenous issues (Rice). Primary, archival research on the Yakut Autonomous Soviet Socialist Republic (ASSR) was undertaken by the lead author during the months of February to June 2019. The archival sources analyzed in this article are housed at the National Library of the Republic of Sakha in Yakutsk, Russia. The sources were selected by way of a purposive sampling technique and analyzed using qualitative content analysis and manual coding techniques. All translations from Russian to English were done by the authors. The article employs a historical institutionalist approach to the study of Indigenous politics in the Yakut ASSR complemented by a constructivist understanding of how ethnic-based collective identities are shaped by historical struggles and political opportunities or constraints (Chandra, 2012; Rice, 2012). The central argument of our article is that historic patterns of popular political incorporation shape, to a large extent, the expression and articulation of Indigeneity in a given country. While path-dependent patterns of incorporation may set the stage for contemporary political expressions and frameworks for organizing, social actors can influence the direction of the course taken.

The article opens with an overview of the concept of Indigeneity and its articulation and expression in different contexts of the globe. This section highlights the diversity of Indigenous-State relations in the Global North and Global South and how Indigenous Peoples, both recognized and unrecognized, are struggling to advance common causes. It also reveals the ways in which governments attempt to avoid their international obligations and responsibilities to Indigenous Peoples by manipulating official definitions of Indigeneity to arbitrarily exclude large portions of the population from self-identifying as Indigenous Peoples. The article then turns to the case study of the Yakut Autonomous Soviet Socialist Republic during the period of 1920 — which marked the beginning of the Soviet Union's "nativization" campaign - until 1991 when the regime collapsed. The case study reveals the ways in which the Yakut (Sakha) people have attempted to carve out an autonomous space for practicing their culture and traditions in the face of the top-down efforts of the USSR to incorporate them into its political system as workers and peasants and despite their adoption of communist ideology. One of these ways to preserve Sakha culture was to share Olonkho epics (described below) that emphasized the classless nature of the Yakut (Sakha) society. The study of Indigeneity in an unlikely place has important ramifications for Indigenous Peoples worldwide who are struggling against colonial-minded governments that have not only deprived Indigenous Peoples of their lands and resources, but also suppressed their right to selfidentification through imposed administrative definitions of Indigeneity.

\section{The Global Politics of Indigeneity}

There is no universal and unambiguous definition of “Indigenous Peoples.” The work of José Martínez Cobo (1986), the former Special Rapporteur of the Sub-Commission on Prevention of Discrimination and Protection of Minorities, has been especially influential in establishing the principle of selfidentification as the key diagnostic for Indigeneity. For example, according to ILO C169 (1989), "selfidentification as indigenous or tribal shall be regarded as a fundamental criterion for determining the groups to which the provisions of this Convention apply" (Art. 1.2). Similarly, UNDRIP (2007) states, 
"Indigenous peoples have the right to determine their own identity or membership in accordance with their customs and traditions" (Art. 33.1). Unlike ILO C169, which outlines a working definition of Indigenous Peoples based on criteria that includes historical continuity, first occupancy of or longstanding connection to lands, colonized condition, and a non-dominant status in society, UNDRIP provides no such definition (Samson \& Gigoux, 2016). In Simpson’s (1997) estimation:

The diversity of the world's indigenous communities is such that no single definition is likely to capture the breadth of their experience and their existence, but may in fact exclude particular groups in its efforts to establish a defined category of indigenous peoples. (p. 22)

It is our position that a strict definition of Indigeneity is neither necessary nor desirable, especially in light of the pressure for a formal definition by governments seeking to manage the recent growth in selfidentified Indigenous groups around the world (Barume, 2010; Forte, 2013).

Recent years have witnessed growing anxiety on the part of governments over the politicization of Indigenous identities and the accompanying demands for greater autonomy from the State (Samson \& Gigoux, 2016). The core demands of Indigenous movements across the globe are those of identity, territory, and autonomy. Identity-based demands center on the struggle for recognition as distinct peoples with special rights in the constitution and laws of their respective countries. Demands for identity include official recognition and protection of Indigenous languages, cultures, and traditions as well as special programs such as bilingual intercultural education, Indigenous health, and community development (Reuque Paillalef, 1998). The demand for territory centers on the need for the preservation, protection, and recuperation of previously held Indigenous lands. Here land represents a space for the spiritual, cultural, and material reproduction of Indigenous Peoples, as opposed to simply an element of production (Ticona Alejo, 2000). Lastly, the demand for autonomy centers on the call for self-determination and self-government within Indigenous territories (Díaz Polanco, 1998). Selfdetermination is a core concept of international customary and treaty law that affirms Indigenous Peoples' rights, conventionally associated with statehood, to sovereignty of governance, territorial integrity, and cultural autonomy (Anaya, 1996). The broader societal understanding of Indigenous identity as ethnic or racial in nature stands in tension with Indigenous Peoples' claims to nationhood (Barker, 2015; Wilkins \& Stark, 2017). The term "national or ethnic minority" does not capture the unique representational needs of Indigenous Peoples. For instance, whereas ethnic minorities are often identified with a given state in which they are numerically small, Indigenous Peoples tend not to identify themselves with a given state but with a given territory. In addition, the rights of minorities are generally framed in individual terms, whereas Indigenous Peoples' rights are collective rights, protected by international law (Barume, 2010).

The passage of UNDRIP marked a watershed moment for the global Indigenous rights movement, affirming Indigenous Peoples' rights to self-identification and self-determination. Governments have responded in a number of ways to offset their responsibilities and obligations under the Declaration. The Canadian government, for example, initially voted against its adoption, as did Australia, New Zealand, and the United States. The Russian government simply sidestepped this debate by abstaining from voting on the passage of UNDRIP. It has also failed to ratify ILO C169. The Russian government classifies the Indigenous Peoples living within its borders, such as the Enets, Oroks, Nenets, and Evenkis, 
as "Indigenous small-numbered peoples of the North, Siberia, and the Far East" whose populations require legal protection (Pika, 1999). According to the federal law About Indigenous Small-Numbered Peoples, in order to meet the government's requirements for designation of Indigenous status, a group of peoples must number fewer than 50,000, maintain a traditional way of life, inhabit remote areas of the country, and identify as a distinct ethnic group (Consultant Plus, 1999; First Peoples Worldwide, 2014). Donahoe and Habeck (2011) suggested that Small People Status implies a lower level of social organization in a hierarchy and that it is not a status to be proud of, to maintain, or to nurture. In Forte's (2013) estimation: "The right to measure involves a power to erase, just as the power to speak for Indigenous Peoples, and to assign their identities, is the power to silence them, permanently" (p. 32). Historically, the Soviet government had developed the legal concept of Indigeneity with the intention of helping "backward" northern communities find their path to communism (Slezkine, 1994, p. 421). Neither the Soviet nor the Russian governments have officially recognized the colonization of Indigenous lands. As a result, Indigenous land claims in the country remain unrecognized (Sidorova, 2019).

In the Global South, governments have adopted a variety of stances toward UNDRIP implementation. While some governments have adopted evasive maneuvers to avoid addressing their Indigenous rights obligations, others have acted as global leaders in this area. In Africa and Asia, governments actively worked to obtain a strict definition of Indigenous Peoples during the drafting of the Declaration that would exclude Indigenous Peoples in their own countries from becoming beneficiaries (Henriksen, 2009). In the absence of such a definition, the Indonesian government, for example, has cast all its citizens as Indigenous, thereby supporting the UNDRIP without recognizing its applicability within its borders (Bertrand, 2011). Nigeria and Kenya, both of whose economies are heavily dependent upon precious resources that are located in Indigenous Peoples' territories, abstained from voting on the Declaration (Kipuri, 2009). In Latin America, Indigenous rights to self-identification and selfdetermination are more widely accepted. Ecuador, the birthplace of Special Rapporteur Martínez Cobo, is regarded as an Indigenous rights pioneer (Van Cott, 2005; Yashar, 2005). The country's 2008 Constitution recognized the plurinational character of the state, the historic goal of Ecuador's Indigenous movement (Rice, 2012). In contrast, in neighboring Peru, Indigenous Peoples have played a limited role in the political life of the country. Outside of the Amazonian region, appeals to Indigenous identity do not resonate in the country (Glidden, 2011). Such regional variation in the politicization of Indigenous identity speaks to the unique history of Indigenous-State relations in a given country and its particular pattern of popular political incorporation.

Constructivism views identities as multiple, fluid, and capable of change depending on economic, social, and political processes (Chandra, 2012). In other words, individuals have multiple identities, some of which are privileged or activated over others depending on the situation or context. For constructivists, all identities are socially constructed - they are developed through social relations with others. As Canessa (2018) has pointed out: "At the risk of stating the obvious: 'indigenous' is not an indigenous concept” (p. 316). A group's identification as Indigenous emerges through particular patterns of engagement and struggle with other social actors (Murray Li, 2000). Although Indigenous identities are socially constructed, they are not automatic; historic patterns of popular political incorporation shape and define their political expression and salience (Rice, 2012). Strong legacies of corporatist or classbased integration, for instance, make the construction of alternative ethnic identities exceedingly 
difficult or, at the very least, tend to undermine Indigenous Peoples' efforts to generate a common framework for organizing and mobilizing. The comparative historical literature on political development suggests that key historical developments generate legacies or path dependencies that help shape future outcomes (Collier \& Collier, 1991; Luebbert, 1991; Mahoney, 2002). Historical institutionalists argue that institutions themselves profoundly shape not only what policies are possible and what political outcomes are likely, but that their preservation is part of our political socialization (Rueschemeyer et al., 1992). In other words, citizens come to accept and value existing institutions and define their own interests and identities in terms of preserving those institutions. In the case of the Soviet Union, to which we are about to turn, class-based organizational forms and principles may have impeded the articulation and mobilization of Indigenous identity for certain groups, but they have not completely precluded this possibility.

\section{From the Yakut Autonomous Soviet Socialist Republic (ASSR) to the Sakha Republic}

The Russian Empire (1721-1917) was a classic multi-national empire where the de facto dominance of the Russian people was established in society and ethnic minorities or inorodtsy (aliens) experienced legal restrictions and were subjected to forced assimilation or "Russification" (Agalarkhanova, 2013). After the October Revolution of 1917 led by the Bolshevik Party of Vladimir Lenin, the government eliminated the special status of aliens, making all citizens equal. The 1918 Constitution declared, "the establishment of any privileges or advantages on the basis of race and ethnicity, as well as oppression of ethnic minorities and restrictions of their equality to other nations, contradicts primary laws of the Russian republic" (cited in Agalarkhanova, 2013, p. 20). According to Slezkine (1994), the application of Marxist-Leninist theory to the creation of the USSR in the 1920s was characterized by hostility to individual rights in favor of group rights. Lenin viewed the communist state as a communal state, governed by the dictatorship of the new dominant class — the proletariat (Kulchickiy, 2014). From the theoretical perspective of Marxism-Leninism, colonized peoples became equated with the working class. Indigenous Peoples were only entitled to special treatment until such time that the consequences of imperialism and colonialism had been cured by communism (see Table 1). Non-working-class groups within the Soviet system included the kulaks (bourgeoisie) and shamans (Indigenous healers). Whereas the Soviet government blamed the kulaks for the country's economic and social problems, they chastised the shamans for being responsible for the "backwardness and ignorance" of Indigenous communities (Slezkine, 1994, p. 62). Thus, as with any religion in the Soviet system, shamanism was viewed as supporting relations of oppression and exploitation by sanctifying them with the authority of religious ideology. 
Table 1. Comparison Between International Legal Perspectives and Marxist-Leninist Views of Indigenous Self-Determination

\begin{tabular}{|c|c|c|}
\hline & $\begin{array}{l}\text { International legal interpretation of } \\
\text { Indigenous self-determination }\end{array}$ & $\begin{array}{l}\text { Marxist-Leninist view of Indigenous } \\
\text { self-determination }\end{array}$ \\
\hline $\begin{array}{l}\text { Origin of the idea of } \\
\text { self-determination } \\
\text { and self-autonomy }\end{array}$ & $\begin{array}{l}\text { Social contract theory: The } \\
\text { government should be guided by the } \\
\text { will of the people governed (Anaya, } \\
\text { 1996, Kly \& Kly, 2001). This right } \\
\text { should be recognized as jus cogens } \\
\text { (fundamental principle of } \\
\text { international law) to the highest rule } \\
\text { of international law. }\end{array}$ & $\begin{array}{l}\text { Marxism-Leninism: The state is a } \\
\text { commune governed by the } \\
\text { dictatorship of the proletariat } \\
\text { (Kulchickiy, 2014; Slezkine, 1994). } \\
\text { The idea of Soviet identity in a } \\
\text { multiethnic state is "national in form } \\
\text { and socialist in content" (Wojnowski, } \\
\text { 2015, p. 2). }\end{array}$ \\
\hline $\begin{array}{l}\text { Justification of the } \\
\text { right to self- } \\
\text { determination by } \\
\text { Indigenous Peoples }\end{array}$ & $\begin{array}{l}\text { The need to denounce the politics of } \\
\text { destruction and assimilation that } \\
\text { Indigenous communities have } \\
\text { experienced in the past (Xanathaki, } \\
\text { 2007). Indigenous empowerment } \\
\text { (Cowan, 2013) and resistance against } \\
\text { centralizing tendencies of the State } \\
\text { (Niezen, 2003). }\end{array}$ & $\begin{array}{l}\text { Creation of the working class } \\
\text { competent in Marxism-Leninism } \\
\text { among Indigenous Peoples in order } \\
\text { to cure the wounds of imperialism } \\
\text { (Liber, 1991; Slezkine, 1992, 1994). } \\
\text { The need to destruct the power of } \\
\text { Indigenous bourgeoisie (kulaks) and } \\
\text { shamans. }\end{array}$ \\
\hline $\begin{array}{l}\text { The difference } \\
\text { between Indigenous } \\
\text { self-determination } \\
\text { and ethnic national } \\
\text { self-determination }\end{array}$ & $\begin{array}{l}\text { Indigenous self-determination does } \\
\text { not include the right to secession, and } \\
\text { it is limited to internal self- } \\
\text { determination through the exercise of } \\
\text { autonomy and self-government } \\
\text { within state borders (Anaya, 1996; } \\
\text { Nordin \& Witbrodt, 2012). }\end{array}$ & $\begin{array}{l}\text { The Indigenous right to autonomy } \\
\text { was determined by population size. } \\
\text { The type of autonomy was also } \\
\text { determined hierarchically, where the } \\
\text { Russians were at the top, and small } \\
\text { Indigenous nations were at the } \\
\text { bottom (Kulchickiy, 2014; Stammler- } \\
\text { Gossmann, 2009). }\end{array}$ \\
\hline
\end{tabular}

Note. Source: Authors' compilation.

As head of government of Soviet Russia (1917-1922) and then of the Soviet Union (1922-1924), Lenin proposed the "Great Compromise" with non-Russian groups that would deliver their incorporation into the revolutionary regime (Liber, 1991). The first component of this project of popular political incorporation was to create an Indigenous intelligentsia by providing upward mobility to governing party members and by destroying the old cultural elite. The policy of korenizatsiia (nativization or Indigenization) sought to fill key management positions with Indigenous representatives specifically trained and educated for this purpose (Slezkine, 1992). Korenizatsiia equated non-Russian languages and cultures with the Russian language and culture. Liber (1991) suggests that this policy provided a 
cover of legitimacy for the largely urban-based revolutionary movement in a mostly agricultural, multiethnic country. As the General Secretary (1922-1953) of the re-named Communist Party of the Soviet Union, Joseph Stalin, declared in April 1923:

In order to familiarize the Soviet power to non-Russian peasantry, we should make it understandable for them through their native tongues. The schools and government bodies should consist of locals who speak local languages and well-acknowledged with laws, traditions, and lifestyles of non-Russian ethnicities. (cited in Kulchickiy, 2014, p. 190)

Despite its efforts to create the "new Soviet nation," the USSR did not attempt to assimilate non-Russian groups into Russian culture and society to the same extent that the Russian Empire did. By promoting the official use of Indigenous languages within the state, the USSR inadvertently preserved a key cultural resource for Indigenous communities.

The second major component of Lenin's project of popular political incorporation was the creation of separate republics by dividing the country along ethnic national-territorial lines (Liber, 1991). The Soviet government declared that all ethnic majorities within non-Russian provinces were "titular," but that a hierarchy defined their administrative-territorial division. The titular nation of the first order was the Russians themselves (e.g., the USSR), the union republics (e.g., the Ukrainian SSR) were the second order, the autonomous republics (e.g., the Yakut ASSR, the Komi ASSR) were the third order, autonomous okrugs (ethnic regions) were the fourth order, and ethnic districts made up the fifth order (Kulchickiy, 2014). For example, in the Ukraine, Ukrainians were the titular nation, but outside of the Ukrainian SSR they were regarded as ethnic minorities by Soviet officials. This hierarchy of autonomous units, which was based on ethnographic research, saw territorial boundaries redrawn in accordance with ethnic boundaries (Stammler-Gossmann, 2009). The vertical integration of ethnic republics, regions and districts not only led to some ethnic groups receiving greater autonomy from the state than others, but it also created the artificial division between small numbered Indigenous Peoples and large ethnic minorities in the USSR that has continued into present-day Russia.

\section{Self-Determination in the Yakut ASSR}

Yakutia is historically part of Russian Siberia. In 1917, the Yakut (Sakha) people constituted 87.1\% of the province's total population, with Russians (6.2\%), Evenki (5\%), Chukchi, Yukagirs, Lamuts, and other small groups making up the remainder (Makarov, 1957). The Soviet literature argues that the Yakut (Sakha) are not native to the land; their ancestors came to Siberia from the Central Asian steppes and assimilated into the local Indigenous tribes (Okladnikov, 1955). Okladnikov (1955) finds that in the XVII century, the Yakut used to say that they would rather live in their original homeland than in a very harsh climate. He also compares the Yakut language and culture with the languages and cultures of Turkic and Mongolian ethnicities such as the Altai people and concludes that the Yakut are not the original inhabitants of Eastern Siberia. According to Soviet author Gavriil Makarov (1957), due to its harsh climate and remote location, the Yakutian province did not attract the attention of Russian settlers. Instead, the Russian Empire turned the province into a penal colony. As maintained by Soviet authorities, the perceived underdevelopment and political "backwardness" of the Yakut (Sakha) population was an outcome of the Russian Empire's assimilationist policy (Makarov, 1957). When the 
Bolsheviks established their power in Yakutia in December 1922, the province became part of the USSR (Argounova-Low, 2012). The local Indigenous intelligentsia was long aware of the resource potential of the province. Gold was discovered in the nineteenth century and the first goldmining operation began in 1908 , followed by the opening of Soviet gold mines in 1925. By the 1960s, diamond operations had started (Argounova-Low, 2012). Resource extraction in the Yakut ASSR dramatically changed the demographics of the province. By the end of the Soviet era, the Yakut (Sakha) people constituted only $33 \%$ of the province's population, while the Russian presence had increased to 51\% (Makarov, 1959).

In 1917, Yakut (Sakha) intelligentsia established a cultural society named Sakha Aimakh (Sakha Kindred). The leaders of the society did not accept the October Revolution, declaring that the Bolsheviks had sabotaged ethnic relations in Russia (Argounova-Low, 2012). By 1920, Sakha Aimakh was closed by Soviet authorities for being bourgeois, nationalist, and anti-Soviet in nature. Subsequent attempts of the Yakut (Sakha) intelligentsia to open similar cultural societies, such as Sakha Omuk (the Sakha People) and Manchaary (named for the Yakut national hero Vasiliy Manchaary), also faltered due to government intervention (Argounova-Low, 2012). Throughout the 1920s and 1930s, the Yakut (Sakha) intelligentsia was persecuted for their "bourgeois nationalism." According to historians of the Soviet era, the term "nationalist" was reserved for those giving anti-Soviet, counter-revolutionary speeches as well as those attempting to take over the government with the support of American and Japanese imperial powers (Zakharov, 2012). The Committee for State Security (KGB) also severely punished individuals accused of ethnic nationalism. According to Article 59-7 of the Criminal Code of the USSR, ethnic nationalism included: "Propaganda and agitation aimed to provoke ethnic and religious hostility and enmity, as well as distribution or production and keeping of literature of the same content" (Dalan, 2003, p. 62). For example, Dalan (Vasiliy Yakovlev), a famous Sakha writer, was once accused of violating Article 59-7 for writing a student paper that argued that Yakutia had joined the USSR by force and which was interpreted by authorities as "anti-Soviet nationalistic agitation" (Dalan, 2003, p. 67). Based on Joseph Stalin's statement that "capitalist heritage is kept alive in ethnic culture," numerous Sakha writers, including Dalan, were accused of being bourgeois nationalists and sent to prison (Dalan, 2003, p. 61).

In light of these dynamics, there was considerable debate among Soviet authorities during the 1920s over whether or not Yakutia should be granted the right to become an autonomous republic (National Archive of the Republic of Sakha, n.d.). According to Korobeynikov (2017), by the 1920s, the Soviet authority had not developed any particular policy toward Indigenous Peoples. He noted that different governmental bodies held distinct positions on the Yakut (Sakha) leadership: Siberian authorities (Sibrevkom) expressed their sympathy toward Yakut (Sakha) political activists, the administrative center of Irkutsk attempted to control them, and Moscow did not have any particular opinion on them (Korobeynikov, 2017). Thus, the policy regarding the Yakut (Sakha) was determined mostly by circumstance. In 1921, representatives of the Yakut (Sakha) intelligentsia, Platon Oyunskiy, Isidor Barakhov, and A. Ageev presented a draft of a resolution on the creation of the Yakut ASSR to the Soviet government (National Archive of the Republic of Sakha, n.d.). Their project was quickly dismissed. In January 1922, the Yakut (Sakha) leader M. Ammosov declared autonomy for Yakutia in the Narkomnats (People's Commissariat for Nationalities; National Archive of the Republic of Sakha, n.d). The final decision about granting Yakutia the right to self-autonomy was made by the Politburo (principal policymaking committee of the Communist Party) with Lenin's approval in February of 1922 (National 
Archive of the Republic of Sakha, n.d.). Platon Sleptsov (Oyunskii), the Yakut (Sakha) political leader and writer, was appointed as head of the first government of the Yakut Autonomous Soviet Socialist Republic (National Archive of the Republic of Sakha, n.d).

The ideas of autonomy and self-government among Yakut (Sakha) regional leaders were influenced by several political events: the emergence of regionalism in Siberia in 1882, the February Revolution, and the Russian Civil War (Argounova-Low, 2012). One of the main goals of the regionalist movement (oblasnichestvo) was the creation of the Siberian Federation, which meant much greater autonomy for Siberia. The regionalist movement inspired the creation of the Confederalist movement in the 1920s (Argounova-Low, 2012). After the February Revolution in 1917, the Russian Tsar Nicholas II abdicated, and the Provisional Government replaced the Tsar in March of that year. In June 1917, the local authorities in the Russian provinces were replaced by local governmental bodies with much wider powers including control over police, education, and other social sectors (Argounova-Low, 2012). Because of this new policy direction, the Yakut (Sakha) intelligentsia became supportive of and sympathetic to the Provisional Government. In the aftermath of the October Revolution of 1917, the Bolsheviks did not immediately seize power in Siberia and the Far East. To obtain full control over the country, the revolutionaries had to continue to fight the White Russians (ruling class) until their defeat in 1923 (Argounova-Low, 2012). The Confederalist group, which was created in the 1920s by the Yakut (Sakha) leader Pavel Ksenofontov, promoted the idea of a confederalist state with equal regional units and land use rights (Argounova-Low, 2012). The Confederalists argued that the status of the Yakut ASSR did not provide for sufficient self-determination and constitutional equality and did not prevent the economic exploitation of the region (Argounova-Low, 2012). In 1928, the Confederalist movement was accused of participating in a counter-revolutionary plot and attempting to overthrow Soviet power to create a bourgeoisie-democratic state in alliance with Japan. In March 1928, all 22 members of the movement were executed (Argounova-Low, 2012).

Despite the intentions of regional leaders to have self-government, the Yakut ASSR did not have real authority. According to Mironov (2003), even though the idea of self-autonomy was initiated by the local Indigenous intelligentsia, the real authority in the decision-making process belonged to the central Soviet government and the ruling party. The 1937 Constitution of the Yakut ASSR declared that:

The political base of the Yakut ASSR is constituted of the unions of workers' representatives who grew up and thrived because of the defeat of capitalist and feudal power and because of the establishment of a dictatorship of proletariat and the liberation of the Yakut nation from oppression of the Tsarist and Russian imperialist bourgeoisie. (cited in Mironov, 2003, p. 21)

Thus, the Yakut autonomous republic was a predominantly class-oriented political organization that did not reflect the Yakut (Sakha) people as an Indigenous Nation. The Yakut (Sakha) people came to be defined by governing authorities as peasants and workers as opposed to the original peoples of Yakutia (Mironov, 2003). 


\section{Sakha Resurgence}

The system of interest group representation in the Soviet Union has been characterized as that of state corporatism (Bunce \& Echols, 1980; Hough, 1983). While corporatism is generally understood as a system in which interest groups become an institutionalized part of the political structure, under state corporatism the state uses interest group structures to control and dominate citizen groups and the interests they are allowed to voice (Collier \& Collier, 1991; Oxhorn, 1998). According to the classic work of Philippe Schmitter (1974):

Corporatism can be defined as a system of interest representation in which the constituent units are organized into a limited number of singular, compulsory, non-competitive, hierarchically ordered and functionally differentiated categories recognized and licensed (if not created) by the state and granted a deliberate representational monopoly within their respective categories in exchange for observing certain controls on their selection of leaders and articulation of demands and supports. (pp. 93-94)

In exchange for nominal rights to autonomy, the Yakut (Sakha) people were obliged to organize and define themselves as workers and peasants. While the Yakut (Sakha) people may have assumed classbased identities and interests before the State, our research shows that within their communities they continued to practice their traditional culture and customs, albeit in adapted form. For instance, while the State referred to the Sakha people as the "Yakut," they maintained their self-identification as the "Sakha." The influential Sakha writer Isidor Barakhov (1924) once published an essay, "Yakutization and the Russian Language," that questioned whether the Yakut (Sakha) people had in fact received the right to autonomy after the Revolution. Barakhov also suggested that the Soviet government promoted the use of Indigenous languages as a vehicle to facilitate the building of Soviet statehood in the country's ethnic republics and regions.

The Soviet government permitted Sakha folklore to be published in both the Russian and Sakha languages. Olonkho is the ancient oral tradition of the Sakha people that includes epic stories about Good and Evil, warriors, gods, and demons (Urastyrov, 1983). Olonkhowas told by trained storytellers who recounted their stories from early morning until late at night, sometimes taking up to three days to tell the entire tale (Omollon, 2000). According to Omollon (2000), olonkho has been performed on the theatre stage since the First Russian Revolution of 1905. By 1957, plays based on olonkho stories were even performed in Moscow. It is impossible to count how many epic stories there are of the Sakha. In 1983, the Siberian Division of the Institute of Language, Literature, and History kept more than 100 records of olonkho (Urastyrov, 1983). The preface to the olonkho story, Legends and Myths of the North, stated that "indigenous literature originated in societies without social classes. The spiritual and esthetic experience of indigenous peoples, collected for thousands of years, became a driving factor in the art of northern writers, who were nurtured by a socialist society" (Sangi, 1985, p. 4). Similarly, the preface to Mighty Djaragyma suggested, "the olonkho expressed the eternal people's dream about a peaceful life laboring under the sky where they belonged ... Olonkho is a memorial to the spiritual culture of the Sakha people" (Urastyrov, 1983, p. 3). Hence, Indigenous literature and oral traditions of storytelling survived under the USSR regime, but these traditions had to be adjusted to fit Soviet ideology. For this reason, Indigenous communities in the past were portrayed as altruistic workers who 
enjoyed a life of labor. The classless nature of olonkho stories, which fed the narrative of a pre-capitalist society, contributed to their survival under communist rule.

In Soviet literature, the Russian colonization of Yakutia is depicted as a form of deliverance and freedom for the Yakut people from the local feudal aristocracy who exploited them. Soviet interpretations of the Sakha legend of Tygyn Darkhan, for example, portrayed him as a despotic leader who exploited his people. In their view, "Russians saved the Yakut people from Tygyn's oppression. The Russian people, mighty and hardworking, helped the Yakut people start a new life" (Okladnikov, 1955, p. 426). According to Soviet narrative, the Russian colonizers were the "saviors" of the Sakha people. Hence, the Soviet government's propaganda used Indigenous legends not only to promote its own ideology, but also to justify its colonial actions. Racism and discrimination against Indigenous Peoples in the Soviet Union were viewed by authorities as a remnant of capitalism and bourgeois nationalism that could only be remedied by a proper Marxist education. The emphasis on the creation of a homogenous Soviet nation under a Marxist-Leninist regime denied the potential for the emergence of ethnic identification and mobilization (Mironov, 2003).

An important element of Indigenous culture that the Soviets did not tolerate was that of shamanism. All religious movements, cults, and churches, including Yakutian shamanism, were politically discriminated against in the USSR (Vasilieva, 2000). Before the October Revolution, shamanism peacefully coexisted with the Russian Orthodox Church even though the Tsarist government and the Church attempted to fight shamanism, which they perceived as an expression of paganism. Shamans were considered by the Bolsheviks as "exploiters of other people's labor" and as leisured classes (Vasilieva, 2000, p. 69). After the Russian Civil War of 1924, the persecution of shamanism became more organized and widespread, forcing many shamans to abandon the practice. The Yakut (Sakha) writers Platon Oyunskiy and Gavril Ksenofontov published articles about the struggles over shamanism, noting that the average Sakha did not clearly distinguish between their Christian and shamanist beliefs, asking for help from both priests and shamans (Vasilieva, 2000). Nevertheless, Soviet propaganda promoted anti-shamanism, calling it a "heritage of dark times, backwardness and ignorance" (Vasilieva, 2000, p. 69). As a result of the government's ban on shamanism, shamanist knowledge of spirituality, traditional medicine, rituals, traditions, moral and ethics was seriously eroded. Following the collapse of the USSR, however, shamanism was resurrected as the traditional religion of the Sakha people (Omollon, 2000).

By the end of the 1980s, $95 \%$ of the Sakha people considered the Sakha language to be their first language, while Indigenous small-numbered peoples in the Yakut ASSR reported less fluency in their Indigenous languages (Evenki 8.5\%, Even 34.7 \%, Yukagir 35.2\%, Chukchi 63.2\%; Sleptsov, 2013, p. 19). By 1986, the percentage of Sakha students admitted to the first year of the local university increased to $80 \%$ of the student population ("Soyuz Nerushimyh?" [Unbreakable Union?], 2001). In that year, a group of officials from the Central Committee of the USSR and the KGB visited Yakutsk, the capital city of Yakutia, due to unrest among students at Yakutsk State University (YSU). From March 29 to 31, 1986, Russian teenagers fought with Sakha students near the YSU campus. On April 1, 1986, a large group of Sakha students gathered around the nearby lake in protest and to ask the Minister of Interior Affairs to punish the Russian teenagers who had provoked the fighting ("Soyuz Nerushimyh" [Unbreakable Union?], 2001). The following day, nearly 700 university students demonstrated in the streets shouting, "Yakutia is for the Yakuts, stop the Russians!" The crowd of youth ended up meeting at 
the university hall, where 21 students gave speeches about their view of the situation ("Soyuz Nerushimyh" [Unbreakable Union?], 2001). The youth accused the police of being inactive. The Central Committee of the Communist Party declared: "The Yakut Area Committee must pay attention to the large failures in interethnic upbringing that led to the nationalistic expressions of the youth of Yakutsk city" ("Soyuz Nerushimyh" [Unbreakable Union?], 2001, para. 16). According to one KGB official, "the KGB is against anti-Soviet, bourgeois nationalism, and it aims to eliminate nationalism in any form" (cited in Dalan, 2003, p. 326). The interethnic conflict in Yakutsk was the first of its kind between the Russians and the Yakut (Sakha) people. On December 27, 1991, one day after the dissolution of the USSR, the Yakut Autonomous Soviet Socialist Republic was officially renamed the Sakha Republic.

\section{Conclusion}

This article has sought to explain how and why Indigenous organization and mobilization looks different in different places. Based on the experiences of the Yakut (Sakha) people under Soviet rule, we found that historic patterns of popular political incorporation shape the articulation and expression of Indigeneity in a country. There is a certain amount of "stickiness" or path dependence to initial patterns of political incorporation that influence contemporary political expressions (Collier \& Collier 1991). In the case of the Soviet Union, the Yakut (Sakha) people were incorporated into the political system by way of Lenin's so-called Great Compromise with non-Russian groups that saw the creation of autonomous republics for large Indigenous groups in exchange for their adoption of communist ideology and assumption of class-based identities and forms of organizing. Despite the top-down efforts of the USSR to smother ethnic nationalism, including a formal ban on certain cultural practices, the Yakut (Sakha) people managed to preserve key elements of their traditional culture and language by actively adjusting them to fit within the Soviet system. By the time the USSR collapsed in 1991, signs of an Indigenous resurgence among the Yakut (Sakha) people had become visible.

Governments play a central role in defining Indigenous identity as well as in formulating social policies and allocating resources to priority concerns. Indigenous Peoples have unique representational needs and governments that continue to cast them as ethnic minorities undermine their rights to selfidentification and self-determination. Indigenous rights can only be adequately protected by Indigenous control over the issues that influence their lives (Xanthaki, 2007). As the case of the Yakut (Sakha) people of Siberia has demonstrated, Indigenous Sovereignty is resurgent around the globe. Indigenous Peoples are increasingly searching for ways to shed what Lucero (2012) has termed "ventriloquist forms of representation" through peasant and worker unions, political parties, or the State so that they may speak with their own voice (p. 287). The concept of being Indigenous in an unlikely place pertains not only to the case of the Yakut (Sakha) people, but to all Indigenous Peoples struggling to reclaim and redefine their Indigeneity, whether that be in the face of intransigent governments, unwelcoming cities, or even within the dictates of their own households and communities.

International Indigenous rights instruments, such as ILO C169 and UNDRIP, play an important role in supporting Indigenous Sovereignty worldwide (Lightfoot, 2016). This may especially be the case for non-recognized Indigenous Peoples in the struggle to advance their rights to self-identification and selfdetermination. Even in cases where governments have refused to ratify or endorse Indigenous rights 
conventions and declarations, Indigenous Peoples are able to appeal to international norms, laws, and organizations to advance their cause (Brysk, 2000). While applying the concept of Indigeneity to peoples and contexts where it is not normally used does run the risk of conceptual stretching (Collier \& Mahon, 1993), changing the qualifying conditions of the concept (such as removing the first occupancy criterion) allows it to be taken up in meaningful ways by new groups seeking recognition not only of their rights but of their very existence by reluctant states.

\section{References}

Agalarkhanova, A. (2013). Nacional'naja politika Rossijskoj imperii i Sovetskoj Rossii v otnoshenii korennyh malochislennyh narodov Severa, Sibiri i Dal'nego Vostoka. [National policy of the Russian Empire and the Soviet Russia towards Indigenous small-numbered peoples of Siberia, the High North, and the Far East.] Gumanitarnye issledovanija v Vostochnoj Sibiri i na Dal'nem Vostoke, 6(26), 18-26.

Alfred, T. (2009). Peace, power, righteousness: An Indigenous manifesto( $2^{\text {nd }}$ ed.). Oxford University Press.

Anaya, J. (1996). Indigenous Peoples in international law. Oxford University Press.

Argounova-Low, T. (2012). The politics of nationalism in the Republic of Sakha (Northeastern Siberia) 1900-2000: Ethnic conflicts under the Soviet Regime. Edwin Mellen Press.

Balzer, M. M., \& Vinokurova, U. A. (1996). Nationalism, interethnic relations and federalism: The case of the Sakha Republic (Yakutia). Europe-Asia Studies, 48(1), 101-120. https://doi.org/ $\underline{10.1080 / 09668139608412335}$

Barakhov, I. (1924). Yakutizatsiia i Russkij yazyk. [Yakutization and Russian language]. Po Zavetam Il'ycha, May-June, 3-4.

Barker, J. (2015). Self-determination. Critical Ethnic Studies, 1(1), 11-26. https://doi.org/10.5749/ jcritethnstud.1.1.0011

Barume, A. K. (2010). Land rights of Indigenous Peoples in Africa (IWGIA Document No. 115). IWGIA.

Bertrand, J. (2011). Indigenous Peoples' rights as a strategy of ethnic accommodation: Contrasting experiences of Cordillerans and Papuans in the Philippines and Indonesia. Ethnic and Racial Studies, 34(5), 850-869. https://doi.org/10.1080/01419870.2010.537358

Bird, K. (2014). Ethnic quotas and ethnic representation worldwide. International Political Science Review, 35(1), 12-26. https://doi.org/10.1177/0192512113507798 
Brysk, A. (2000). From tribal village to global village: Indian Rights and international relations in Latin America. Stanford University Press.

Bunce, V. \& Echols, J. M. (1980). Soviet politics in the Brezhnev era: Pluralism or corporatism? In D. R. Kelley (Ed.), Soviet politics in the Brezhnev era (pp.1-26). Praeger.

Canessa, A. (2018). Indigenous conflict in Bolivia explored through an African lens: Towards a comparative analysis of Indigeneity. Comparative Studies in Society and History, 60(2), 308337. https://doi.org/10.1017/S0010417518000063

Chandra, K. (2012). Constructivist theories of ethnic politics. Oxford University Press. https://doi.org/10.1093/acprof:oso/9780199893157.001.0001

Collier, R. B. \& Collier, D. (1991). Shaping the political arena: Critical junctures, the labor movement, and regime dynamics in Latin America. University of Notre Dame Press.

Collier, D. \& Mahon, J. E. (1993). Conceptual “stretching” revisited: Adapting categories in comparative analysis. The American Political Science Review, 87(4), 845-855. https://doi.org/10.2307/2938818

Consultant Plus. (1999). Ogarantiyah prav korennyh malochislennyh narodov Rossiyskoy Federatsii [Federal law from the State Duma of the Russian Federation about Indigenous small numbered peoples]. http://www.consultant.ru/document/cons doc_LAW_22928/

Cowan, A. (2013). UNDRIP and the intervention: Indigenous self-determination, participation, and racial discrimination in the Northern Territory of Australia. Pacific Rim Law and Policy Journal, 23(2), 247-310.

Dalan, V. (2003). Dalan. Zhizn'i sud'ba moja. [Dalan. My life and destiny]. Bichik.

Díaz Polanco, H. (1998). La autonomía, demanda central de los pueblos indígenas: Significado e implicaciones [Autonomy, central demand of Indigenous Peoples: Meaning and implications]. In V. Alta, D. Iturralde, \& M. A. López Bassola (Eds.), Pueblos indígenas y estado en América Latina (pp. 213-220). Editorial Abya Yala.

Donahoe, B. \& Habeck, J. O. (Eds.). (2011). Reconstructing the house of culture: Community, self, and the makings of culture in Russia and beyond. Berghahn Books.

First Peoples Worldwide. (2014, February 19). Who are the Indigenous Peoples of Russia? Cultural Survival. https://www.culturalsurvival.org/news/who-are-indigenous-peoples-russia

Forte, M. C. (Ed.). (2013). Who is an Indian? Race, place, and the politics of Indigeneity in the Americas. University of Toronto Press. https://doi.org/10.3138/9781442667990

Glidden, L. M. (2011). Mobilizing ethnic identity in the Andes. Lexington Press. 
Henriksen, J. B. (2009). The UN Declaration on the Rights of Indigenous Peoples: Some key issues and events in the process. In C. Charters \& R. Stavenhagen (Eds.), Making the Declaration work: The United Nations Declaration on the Rights of Indigenous Peoples (pp. 79-85). IWGIA.

Hough, J. F. (1983). Pluralism, corporatism and the Soviet Union. In S. G. Solomon (Ed.), Pluralism in the Soviet Union (pp. 37-60). Palgrave Macmillan. https://doi.org/10.1007/978-1-349-066179 3

International Labour Organization's (ILO) Convention 169-Indigenous and Tribal Peoples, June 27, 1989. https://www.ilo.org/dyn/normlex/en/f?p=NORMLEXPUB:12100:0::NO::P12100 ILO CODE:C169

Khazanov, A. M. (1995). After the USSR: Ethnicity, nationalism and politics in the Commonwealth of Independent States. University of Wisconsin Press.

Kipuri, N. (2009). The UN Declaration on the Rights of Indigenous Peoples in the African context. In C. Charters \& R. Stavenhagen (Eds), Making the Declaration work: The United Nations Declaration on the Rights of Indigenous Peoples (pp. 252-263). IWGIA.

Kly, Y. N. \& Kly, D. (Eds). (2001). In pursuit of the right to self-determination: Collected papers \& proceedings of the First International Conference on the Right to Self-Determination \& the United Nations Geneva 2000. Clarity Press.

Korobeynikov, A. (2017). Jakutskaja avtonomija: Postimperskie politicheskie proekty jakutskoj intelligencii, 1905-1922 gg. [Yakut autonomy: Postimperial political projects of the Yakut intelligentsia, 1905-1922]. Ab Imperio, 2017(3), 77-118. https://doi.org/ $\underline{10.1353 / \mathrm{imp} .2017 .0055}$

Kroeber, C. (2017). Exploring the impact of reserved seat design on the quality of minority representation. Ethnopolitics, 16(2), 196-216. https://doi.org/10.1080/17449057. $\underline{2015.1051326}$

Krook, M. L., \& O’Brien, D.Z. (2010). The politics of group representation: Quotas for women and minorities worldwide. Comparative Politics, 42(3), 253-272. https://doi.org/10.5129/ $\underline{001041510 X 12911363509639}$

Kulchickiy, S. (2014). Formirovanie Sovetskih Titul'nyh Nacij [Building of the Soviet titular nations]. Codrul Cosminului, $X X(1), 181-192$.

Laruelle, M. (2013). Russia's Arctic strategies and the future of the Far North. Routledge.

Liber, G. (1991). Korenizatsiia: Restructuring Soviet nationality policy in the 1920s. Ethnic and Racial Studies, 14(1), 15-23. https://doi.org/10.1080/01419870.1991.9993696 
Lightfoot, S. (2016). Global Indigenous politics: A subtle revolution. Routledge. https://doi.org/10.4324/9781315670669

Lublin, D. \& Wright, M. (2013). Engineering inclusion: Assessing the effects of pro-minority representation policies. Electoral Studies, 32(4), 746-755. https://doi.org/10.1016/ j.electstud.2013.06.001

Lucero, J. A. (2012). Indigenous politics: Between democracy and danger. In P. R. Kingstone \& D. J. Yashar (Eds.), Routledge handbook of Latin American politics (pp. 285-301). Routledge. https://doi.org/10.4324/9780203860267.ch19

Luebbert, G. M. (1991). Liberalism, fascism, or social democracy: Social classes and the political origins of regimes in interwar Europe. Oxford University Press.

Mahoney, J. (2002). The legacies of liberalism: Path dependence and political regimes in Central America. Johns Hopkins University Press.

Makarov G. G. (1957). Obrazovaniye Yakutskoj ASSR. [The creation of the Yakut ASSR]. Yakutsk Book Press.

Martínez Cobo, J. (1986). The study of the problem of discrimination against Indigenous populations (Vols. 1-5; United Nations Document E/CN.4/Sub.2/1986/7). United Nations.

Mironov, D. (2003). Gosudarstvenno-pravovoe Razvitiye YASSR i Respubliki Sakha (Yakutiya). [State and legal development of Yakut ASSR and the Republic of Sakha]. In Respublika Saha (Jakutija): Ot avtonomii k sovremennojgosudarstvennosti (pp. 19-39). Bichik.

Murray Li, T. (2000). Articulating Indigenous identity in Indonesia: Resource politics and the tribal slot. Comparative Studies in Society and History, 42(1), 147-179. https://doi.org/10.1017/ $\underline{\text { S0010417500002632 }}$

National Archive of the Republic of Sakha [Website]. (n.d.). https://e.nlrs.ru/

Niezen, R. (2003). The origins of Indigenism: Human rights and the politics of identity. University of California Press. https://doi.org/10.1525/california/9780520235540.001.0001

Nordin, R. \& Witbrodt, M. A. (2012). Self-determination of Indigenous Peoples: The case of the Orang Asli. Asia Pacific Law Review, 20(2), 189-210. https://doi.org/10.1080/ $\underline{10192557.2012 .11788260}$

Okladnikov, A. (1955). Istoriya Yakutskoi ASSR. [History of the Yakut ASSR]. USSR Academy of Sciences.

Omollon, S. (2000). Vospitaniye Istoriei [Lessons from history]. Administration of the President and the Government. 
Oxhorn, P. (1998). Is the century of corporatism over? Neoliberalism and the rise of neopluralism. In P. Oxhorn \& G. Ducatenzeiler (Eds.), What kind of democracy? What kind of market? Latin America in the age of neoliberalism (pp. 195-217). Pennsylvania State University Press. https://doi.org/10.5325/j.ctv14gpfhw.13

Papillon, M. (2012). Adapting federalism: Indigenous multilevel governance in Canada and the United States. Publius: The Journal of Federalism, 42(2), 289-312. https://doi.org/10.1093/publius/ pjr032

Pika, A. (1999). Neotraditionalism in the Russian North: Indigenous Peoples and the legacy of Perestroika. University of Alberta Press.

Reuque Paillalef, I. (1998). La identidad es un asunto de afirmación de uno mismo. In V. Alta, D. Iturralde, \& M. A. López Bassola (Eds.), Pueblos indígenas y estado en América Latina (pp. 221238). Editorial Abya Yala. http://digitalrepository.unm.edu/cgi/viewcontent.cgi?article= $1395 \&$ context=abya_yala

Rice, R. (2012). The new politics of protest: Indigenous mobilization in Latin America's neoliberal era. University of Arizona Press.

Rueschemeyer, D., Stephens, E. H. \& Stephens, J. D. (1992). Capitalist development and democracy. University of Chicago Press.

Samson, C. \& Gigoux, C. (2016). Indigenous Peoples and colonialism: Global perspectives. Polity Press.

Sangi, V. (1985). Legendy i mify Severa [Legends and myths of the North]. Sovremennik.

Schmitter, P. C. (1974). Still the century of corporatism? The Review of Politics, 36(1), 85-131. https://doi.org/10.1017/S0034670500022178

Sidorova, E. (2019). Circumpolar Indigeneity in Canada, Russia, and the United States (Alaska): Do differences result in representational challenges for the Arctic Council? Arctic, 72(1), 71-81. https://doi.org/10.14430/arctic67955

Simpson, T. (1997). Indigenous heritage and self-determination (IWGIA Document No. 86). IWGIA.

Sleptsov, P. (Ed). (2013). Sovremennaya Etnoyazykovaya situaciya v Respublike Sakha (Yakutia). [The modern ethno-linguistic situation in the Republic of Sakha (Yakutiya)]. Nauka.

Slezkine, Y. (1992). From savages to citizens: The cultural revolution in the Soviet Far North, 19281938. Slavic Review, 51(1), 52-76. https://doi.org/10.2307/2500261

Slezkine, Y. (1994). The USSR as a communal apartment, or how a socialist state promoted ethnic particularism. Slavic Review, 53(2), 414-452. https://doi.org/10.2307/2501300 
Soyuz nerushimyh? [Unbreakable union?]. (2001, April 29). Nezavisimaya Gazeta. http://www.ng.ru/ ever/2001-04-29/15 union.html

Stammler-Gossmann, A. (2009). Who is Indigenous? Construction of 'Indigenousness' in Russian legislation. International Community Law Review, 11(1), 69-102. https://doi.org/ $\underline{10.1163 / 187197309 X 401415}$

Ticona Alejo, E. (2000). Organización y liderazgo Aymara: La experiencia indígena en la política Boliviana, 1979-1996 [Aymara organization and leadership: The Indigenous experience in Bolivian politics, 1979-1996]. Universidad de la Cordillera.

United Nations Declaration on the Rights of Indigenous Peoples (UNDRIP), September 13, 2007. https://www.un.org/development/desa/indigenouspeoples/wp-content/uploads/sites/ 19/2018/11/UNDRIP_E_web.pdf

Urastyrov, K. (1983). Moguchij D'agaryma:Jakutskijgeroicheskij jepos-olonho. [Mighty Djaragyma: Yakutian heroic epic story-Olonkho]. Yakutsk Book Press.

Van Cott, D. L. (2005). From movements to parties in Latin America: The evolution of ethnic politics. Cambridge University Press. https://doi.org/10.1017/CBO9780511756115

Vasilieva, N. (2000). Jakutskoe shamanstvo, 1920-1930-e gg. [Yakutian shamanism in the 1920s-1930s]. Yakut Academy of Sciences.

Wilkins, D. E., \& Stark, H. K. (2017). American Indian politics and the American political system. Rowan \& Littlefield.

Wojnowski, Z. (2015). The Soviet people: National and supranational identities in the USSR after 1945. The Journal of Nationalism and Ethnicity, 43(1), 1-7. https://doi.org/10.1080/ $\underline{00905992.2014 .953467}$

Xanthaki, A. (2007). Indigenous rights and United Nations standards: Self-determination, culture and land(Vol. 52). Cambridge University Press. https://doi.org/10.1017/CBO9780511494468

Yashar, D. J. (2005). Contesting citizenship in Latin America: The rise of Indigenous movements and the postliberal challenge. Cambridge University Press. https://doi.org/10.1017/ CBO9780511790966

Zakharov, V. P. (2012). Vlast' i obschestvo: Obvinyeniya v burzhuaznom nacionalizme v Yakutii v 19201930-h gg. [Power and society: Charges of bourgeois nationalism in Yakutia in the 1920-1930s of the XXth century]. Vestnik SVFU, 9(2), 89-94. 